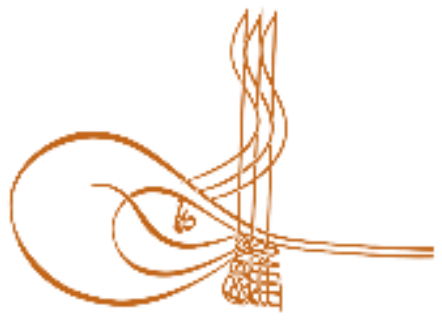

www.turkishstudies.net/social
Turkish Studies - Social Sciences

eISSN: $2667-5617$

Research Article / Araştırma Makalesi

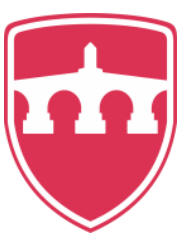

INTERNATIONAL

BALKAN

UNIVERSITY

Sponsored by IBU

\title{
Türkiye Turizm Tanıtımında Gastronomik Değerlerin Yeri*
}

The Role of Gastronomic Values in the Promotion of Turkey's Tourism

$$
\text { Cihan Seçilmişs }^{* *} \text { - Esra Soydan }{ }^{* * *}
$$

\begin{abstract}
This study aims to find out the importance of the use of gastronomic values in the promotion of tourism activities and what can be done to determine the current status of tourism and gastronomy in Turkey. The sample of the study consisted of the people chosen with the use of snowball sampling. It was important in determining participants that they had relevant knowledge about gastronomy tourism. In the study, semistructured questionnaire was used as a data collection tool. The participants were asked about the awareness of the Turkish cuisine, what the promotional activities should be, the evaluation of the things that the prominent countries do with their cuisine, what are the shortcomings and where they can start, and where they can express their views on gastronomic tourism in general. Between the dates of February 15, 2019 and April 8, 2019, 9 people were interviewed face-to-face and with 1 person from a distance. Descriptive analysis method, one of the qualitative data analysis methods, was used in the analysis of the data. When the findings of the research were examined, it was found that participants tended to focus on the fact that gastronomic tourism is not known adequately and that it could not be used effectively in Turkey. One of the most important problems is that people could not work together in the country in the introduction of Turkish cuisine sufficiently. It was also found that it is important to focus on the importance of preserving the local cuisine and culture, to serve the elements of Turkish cuisine in the restaurants in their original forms and to provide information about Turkish cuisine in the brochures and advertisements of the agencies and tour operators operating in the sector in connection with the agencies abroad.
\end{abstract}

Structured Abstract: Introduction The aim of this study is to determine the problems of gastronomic tourism in Turkey and what needs to be done by asking experts' opinions, and to develop solutions. In this context, the study was designed as a descriptive qualitative study aimed at identifying problems. In the research, snowball sampling method, which is one of the purposeful sampling methods, was used. As a result of descriptive analysis of the data obtained from the study, the current situation of Turkish gastronomy is presented as a set of problems.

\footnotetext{
* Bu çalışma Eskişehir Osmangazi Üniversitesi BAP birimi tarafından 201825A112 nolu proje kapsamında desteklenmiştir.

** Doç. Dr., Eskişehir Osmangazi Üniversitesi, Turizm Fakültesi, Turizm İşletmeciliği Bölümü

Assoc. Prof. Dr., Eskisehir Osmangazi University, Faculty of Tourism, Department of Tourism

ORCID 0000-0001-6781-0997

cihansecilmis@gmail.com

**** Uzman, Eskişehir Osmangazi Üniversitesi

Specialist, Eskisehir Osmangazi University

ORCID 0000-0003-2652-901X

esrakmoglu11081981@gmail.com

Cite as/ Atıf: Seçilmiş, C., Soydan, E. (2020). Türkiye turizm tanıtımında gastronomik değerlerin yeri, Turkish Studies

- Social, 15(2), 365-385. https://dx.doi.org/10.29228/TurkishStudies.40016

Received/Geliş: 05 December/Aralık 2019

Checked by plagiarism software

Accepted/Kabul: 25 February/Şubat 2020

Published/Yayın: 29 February/Şubat 2020

Copyright $(C)$ INTAC LTD, Turkey

CC BY-NC 4.0
} 


\section{Results}

\section{Current Situation of Gastronomic Tourism in Turkey}

According to the participants, gastronomic tourism is a very important alternative form of tourism for Turkey. When asked to evaluate gastronomic tourism in Turkey, there were participants who thought it was a popular topic and believed that many things could be done.

It has been stated by the participant P10 that we are at the beginning of the gastronomic tourism, that we can achieve good things and that we should be meticulous in doing so. On the other hand, participants P2 and P9 have indicated that gastronomic tourism is an untapped resource, and that we do not know this type of tourism very well.

The problems encountered during the evaluation of gastronomic tourism in Turkey were evaluated item by item in accordance with the opinion of the participants.

\section{Lack of Knowledge on Turkish Cuisine}

Participants' opinions were asked about the view that "Turkish cuisine is one of the three most important cuisines in the world together with French and Chinese cuisines,". Participants working abroad in different countries, participating in competitions and events, and traveling to many parts of the world agree that our cuisine is a rich one but it is not promoted.

\section{Position of Competitors}

There are many countries in the world that stand out with their gastronomy. Spain, Italy, France, China and Japan are known as successful countries that come to mind when gastronomic tourism is mentioned today. The participants stated that these cuisines are world-famous cuisines and that there are products and restaurants belonging to these cuisines in many cities of the world. However, Peruvian, Thai and Lebanese cuisines were also among cuisines that the interviewers drew attention to.

\section{Problems Related to Competitions, Festivals and Organizations}

It is discussed whether the competitions organized to develop and bring gastronomic tourism to the fore, and the various organizations have produced results that are in accordance with their purpose. Organizing many events is a waste of resources and time.

\section{Positioning of Products with Geographical Indication}

Products with geographical indication are known to be effective in competition and promotion of the country. The use of geographical indication to be used in the foreground for promotion is supported by the participants. However, the need for correct positioning of the products is emphasized.

\section{Agriculture}

The fact that gastronomy starts from the soil, and the relationship between tourism policies and food policies are some of the most important issues today. The importance of efficient agriculture and obtaining quality products were expressed by participants P5 and P6.

\section{The Effect of All Inclusive System on Gastronomic Tourism}

Considering that the places where tourists stay are considered as a means of promotion, the examples of Turkish cuisine offered in these places should be prepared with care. It is important that the presentations of Turkish cuisine to be done in accordance with their original and that the traditional and local tastes be presented correctly.

\section{Conclusion and Recommendations}

Participants shared the need for gastronomy stakeholders to act as a union within the country. Public, private sector, educational institutions and non-governmental organizations should act together for the gastronomy of Turkey. It was stated that special products and concepts should be determined for an effective promotional activity. Based on the fact that quality products will promote themselves, and as a result people will be after them, we need to produce healthy and quality products from field to table. It is a common idea of all participants that our culinary richness should be registered as soon as possible by making inventory and 
archival studies. It is stated that all individuals who are active in the promotion of Turkish cuisine should receive the right training, and that it is essential that information about Turkish cuisine be delivered to everyone in the sector. UNESCO Cities of Gastronomy need to be brought to the fore. It is important that products with geographical indication and our gastronomic culture be designed to be presented to the global market. Original works for gastronomy should be developed in museums, exhibitions and art events. Participants stated that fairs, competitions and some organizations reach only a limited number of people, but the aim of cultural promotion is to reach a wider audience. The target audience can be reached by the use of digital spaces, social media and mobile apps.

The state, private sector and society should jointly support Turkish gastronomy and cooperate. country.

- In order to keep the Turkish dining culture alive, campaigns must be organized throughout the

- It is necessary to elevate the cuisine that is based on local products.

- Federations and associations should agree to act together and in coordination.

- It is necessary to understand and involve each member in gastronomic tourism.

- Assuming that gastronomy is an interdisciplinary study, it should be ensured that people in special fields such as history, geography, anthropology, agriculture, chemistry, marketing, product designers and kitchen professionals should work together.

- Turkish Cuisine Research Institute should be established.

- Standard recipes of Turkish food and beverages should be created, and inventory studies should be carried out. We need to have elements such as terminology, vocabulary, cooking techniques and the name of the cooking utensils used registered.

- Cities should organize gastronomic events together with their sister cities abroad. activities.

- Local and regional administrations should be encouraged to focus on gastronomic tourism oriented

- Mediterranean type of nutrition should be brought to the fore, and it should be stressed that Turkey has a Mediterranean cuisine.

- Tour programs based on gastronomic tourism should be created, and package tours including visits to food and beverage companies should be offered.

- Tasting activities with local foods should be added in tour programs.

- Tasting activities should be arranged in such a way as to allow the purchasing of products. country basis.

- Food and wine routes should be prepared as a priority. Gastronomy routes should be prepared on

- Gastronomy tours can be expanded by works that integrate farm visits with rural tourism.

- Turkish cuisine presentations of hotels in the all-inclusive system should be meticulously prepared and supervised.

- Activities that offer an authentic experience based on cultural identity should be encouraged.

Keywords: TourismGastronomy Tourism, Promotion, Turkish Cousine, Culture

Öz: Bu çalışmanın amacı, Türkiye'de turizm tanıtım faaliyetlerinde gastronomik değerlerin kullanımının önemi, neler yapılabileceği ve Türkiye'de gastronomi turizminin mevcut durumunun belirlenmesidir. Çalışmanın örneklemi kartapu örnekleme ile belirlenen kişilerden oluşmaktadır. Katılımcılar belirlenirken gastronomi turizmi hakkında bilgi sahibi olmalarına dikkat edilmiştir. Araştırmada veri toplama aracı olarak yarı yapılandırılmış anket formu kullanılmıştır. Görüşmecilere, Türk mutfağının bilinirliği, tanıtım 
faaliyetlerinin neler olması gerektiği, mutfaklarıyla öne çıkan ülkelerin yaptıklarının değerlendirilmesi, hangi konularda eksikliklerin olduğu ve yetkili olsalar nereden başlayacakları ve genel olarak gastronomi turizmine yönelik görüşlerini ifade edebilecekleri sorular yöneltilmiştir. 15 Şubat 2019 ve 08 Nisan 2019tarihleri arasında 9 kişi ile yüzyüze ve uzak mesafedeki bir kişi ile sanal ortam üzerinden görüşmeler gerçekleştirilmiştir. Verilerin çözümünde nitel veri analizi yöntemlerinden betimsel analiz yöntemi tercih edilmiştir. Araştırmanın bulguları incelendiğinde; katılımcılar Türkiye'de gastronomi turizminin yeterince bilinmediği ve kullanılamadığı üzerinde durmaktadırlar. Gastronomi turizmi ile ilgili kişilerin ülke içinde birlikte hareket edememesi ve Türk mutfağının yeterince tanıtılamaması önemli sorunların başında gelmektedir. Yerel mutfağın ve kültürün korunması, restoranlarda Türk mutfağının aslına uygun olarak sunulmasının ve Yurt dışı bağlantılı çalışan acenta ve tur operatörlerinin tanıtım broşürlerinde ve reklamlarında Türk mutfak kültürü hakkında bilgi verilmesinin önemine dikkat çekilmektedir.

Anahtar Kelimeler: Turizm, Gastronomi turizmi, Tanıtım, Türk mutfağı, Kültür

\section{Giriş}

Son zamanlarda gastronomik değerlerin turistik bir motivasyon haline gelmeye başlaması gastronomi turizmi konusunda yapılan çalışmaların da artmasını sağlamıştır. Gastronomi turizmine katılanlar, seçimlerinde bölgenin gastronomi potansiyellerine göre tercih yapmakta veya araştırmalar yaparak yeni yerler keşfetmek istemektedir. Gastronomi amaçlı seyahat eden turistlerin birçoğu gittikleri yerlerde bölgesel yiyecekleri tadarak, yemek tarifleri alarak ve bazı ürünleri evlerine götürerek bunları aileleri ve çevreleriyle paylaşmakta, böylelikle bölge tanıtımına ve gelirine katkı sağlamaktadırlar (Marzella 2008, Cömert ve Sökmen, 2017). Gastronomik motivasyonlarla seyahat eden bir turist sadece açlığını gidermek için değil, ünlü ve yeni açılan bir mekanı ziyaret etmek için uzun yollar gidebilen, tatil programını yemek festivallerini, mevsimlik sebze ve meyveleri hesaba katarak planlayan turisttir (Akgöl, 2012).

Gastronomik değerlerin turizm sektöründe değerlendirilebilmesi, destinasyonların ekonomik kalkınması ve yerel kültürün devamı açısından önemlidir (Okumuş, vd., 2007). Gastronomi turizmi mevsimlik olmadığından dolayı deniz turizminden faydalanamayan bölgeler için de alternatif bir turizm çeşidi olmaktadır. Ayrıca gastronomik unsurların turizm hareketliliğinde çekici arz unsurları olarak kullanımı destinasyonların cazibesinde ve pazarlanabilirliklerinin arttırılmasına fayda sağlayabilmektedir.

Gastronomi, bölgelerin sahip olduğu mutfak kültürünü ulusal ve uluslararası çapta tanıtmayı başardığı için önemli bir noktadadır. Dünya Gıda Seyahat Birliği (WFTA, 2016), tarafından yapılan bir çalışmada Psiko-Mutfak profilini araştırılmıştır. Çalışmada katılımcıların \%18'i kendisini gurme olarak kabul ederken, \%46'sı etnik olarak tanımlamış ve gittikleri yerlerin geleneksel mutfaklarını ve tariflerini araştırdıklarını belirtmişlerdir.

Turizme katılmak isteyen, henüz karar vermemiş potansiyel turistleri bilgilendirmek ve ikna etmek için yapılması gereken tanıtım faaliyetleri büyük önem taşımaktadır. Dünyada geliştirilmekte olan stratejiler, destinasyonların doğrudan tanıtımı ve pazarlanması üzerinde yoğunlaşmaktadır (Tosun ve Bilim, 2004). Bir destinasyonun tanttılma biçimi, o destinasyona gelen turistlerin yaptıkları aktiviteleri biçimlendirmekte rol oynamaktadır (Laws, 1995). Tanıtma faaliyetlerinde ön plana çıarılan kültürel unsurlar ile bir ülke ve değerleri en kalıcı şekilde anlatabilir. Gastronominin ülke markalaşmasında ve turizm politikasındaki önemi etkin tanıtım politikalarıla desteklenmelidir.

Bu çalışmada; Türkiye'deki gastronomi turizmine ilişkin mevcut durumun ortaya konarak gastronomik değerlerin ülke tanıtımındaki yerine ilişkin geliştirici öneriler sunulması amaçlanmıştır. Türkiye, gerek sahip olduğu turistik arz kaynakları, gerekse eşsiz ve zengin bir mutfak kültürü ile önemli bir turistik destinasyon ve gastronomi turizm açısından da potansiyeli yüksek bir ülkedir. Ancak gastronomi turizminden yeteri kadar yararlanamadığı da ortadadır. Bu nedenle sorunların 
uzman görüşleri doğrultusunda tespit edilmesi gelecek planları ve atılması gereken adımlarda yetkililere yol gösterebilecektir.

\section{Gastronomi Turizmi ve Önemi}

Turizm Terimleri Sözlüğü (1999) gastronomi turizmini, “yemek zevki konusunda özel ilgisi olan insanların, bu anlamda ilginç olan yerlere yaptıkları ziyaretler" olarak tanımlamıştır. UNWTO (2012) gastronomi turizmi kavramını, seyahatlerini tamamen ya da kısmen bir yerin mutfağını tatmak isteyen veya gastronomik etkinliklere katılmayı planlayan turistler için kullanmaktadır. Santich (2004), yiyecek ve içeceğin sadece bir bölümü içinde olsa seyahatin motivasyon faktörü olduğu belirtmiştir. Karim ve Chi (2010), "insanların yiyeceklerle olan deneyimlerini tanımlayan turizm şekli” olarak gastronomi turizmini tanımlamaktadır.

Geniş kapsamda kullanılan "gastronomi turizmi” terimi, ziyaret edilen ülkenin veya bölgenin kültürünü tanımak ve eşsiz yeme ve içme deneyimleri peşinde olmak için gerçekleştirilen etkinlikler olarak tanımlanmaktadır. Özel bir yemeği tatmak, yemeklerin üretim süreçlerini görmek veya ünlü bir şefin yaptığı yemeği yemek ve otellerde turistler için yemeklerin hazırlanması yerine, yerel yiyecek ve içeceklerle ilgili deneyim yaşamak amacıyla turistlerin seyahat etmesi de gastronomi turizmi içerisinde değerlendirilmektedir (Yüncü, 2010: 29).

Tikkanen (2007) kendisinden önceki çalışmaları inceleyerek bir yerin ziyareti için yiyecek ile bağlantısı olan motivasyonları sıralamıştır. Bu beş madde:

- Turistik çekicilik olarak yemek

- Turizm ürünü bileşeni olarak gıda ürünleri

- Turizmde bir deneyim olarak yiyecek

- Kültürde yiyeceklerin rolü

- Turizm- yiyecek üretimi arasındaki bağlantılar

Tüm tatil deneyimini etkileyen yerel yiyeceklerin tadımı, turizm ve gastronomi arasındaki sıkı ilişkiyi göstermektedir ve bir destinasyonun kültürel anlamının yaratılmasını etkilemektedir (Hall ve Mitchell, 2002). Yerel mutfak kültürü ve deneyimi, turistlerin karar alma süreçlerinde önemli rol oynamaktadır (Cohen ve Avieli, 2004).

Dünyada turizm kazancının \%30'luk payını gastronomi turizminin oluşturduğu belirtilmektedir (Durlu Özkaya ve diğ.2013: 14). Gastronomi turizm bileşeni olmasıyla birlikte, turistlerin harcamalarının önemli bir bölümünü yiyecek ve içeceğe yaptıkları görülmektedir. Yapılan araştırmalar, turistlerin bütçesinde yeme ve içme harcamaları oranının $\% 40$ olduğunu göstermektedir (Boyne, Williams ve Hall, 2002).WFTA(2016) ise gastronomi turistlerinin seyahatleri sirasındaki harcamaların \% 25'inin yeme-içme amaçlı olduğunu ifade etmektedir.

Gastronomi turizmi destinasyonlar için büyük önem taşımaktadır. Fransa, İtalya, İspanya, Tayland, Çin gibi ülkeler, bölgesel kalkınma için yerel gastronomi kültürünü harekete geçirmekte ve turizm stratejilerini bu doğrultuda planlamaktadır. Gastronomi, toplumların kendi içlerinde bir konu olmaktan öte ülke pazarlamasında ve tanıtımında önemli pay sahibidir. Gastronomi doğru bir yatırım aracı olarak kullanıldığında, sürdürülebilir bir ekonomik getiri kaynağı oluşturmaktadır. LopezGuzman ve Sanchez-Canizares (2012) yiyeceğin turizmde başlıca rollerinden biri olarak destinasyonları farklılaştırmanın etkili olduğunu belirtmişlerdir.

Quan ve Wang (2004) destinasyonların tanıtım ve pazarlamasında gastronomi turizminin etkilerini sıralamışlardır. İlk olarak gastronomi turizmi özellikle kırsal alanlarda, tarımsal ürünlere değer katmak ve ekonomiyi canlandırmak için alternatif fırsatlardan olabilir. İkinci olarak yöresel yiyecekler bakımından zengin olan bölgeler, gıda ile ilgili etkinliklerle turistik sermaye haline getirilebilir. Yerel yiyecekler pazarlanarak bu bölgeler cazibe merkezlerine dönüştürülebilir. Üçüncü 
olarak yiyecekler tek başına organize edilebilir ya da diğer çekiciliklerin içinde veya büyük etkinlikler içinde bir parça olarak sunulabilir. Dördüncü olarak yemek festivalleri ve gastronomi etkinlikleri bölgenin yerel kimliğinin zenginleştirilmesi için kullanılan kaynaklardan birdir.

Yoğun rekabetten dolayı farklılaşmak isteyen turizmciler bu farklılaşmada yerel mutfakları kullanma yoluna gitmektedirler (Okumuş vd. 2013; Bezirgan ve Koç 2014; Yılmaz ve Özdemir 2015).Ekonomiye olan katkısı bölgesel kalkınmayı, özellikle de kırsal bölgelerin gelişiminin sağlanması ile ilgilidir (Deveci vd., 2013). Ekonomik etkilerinden biri de yerel kaynakların kullanılmasından dolayı ev sahibi ülkeye para kazandırmasıdır, bunun sonucunda ekonomik sızıntı azalmaktadır (Hall ve Mitchell, 2002:83). Ayrıca gastronomi turizmi yöresel ürünlerin ihracatına da olanak sağlamaktadır. Türk kahvesini deneyimleyen bir turist, ülkesine dönerken kahve, cezve gibi şeyler satın almaktadır; yine zeytinyağı ve peynir tadımı sonrasında bu ürünler ihraç edilmektedir. Destinasyonların yerel ürünler kullanarak farklılaşması; tanıtım yapmak, cazibe oluşturmak, ekonomiyi canlandırmak için önemlidir. Yerel ürünlere değer katarak çiftçi ve üreticilerin kalkınması sağlanır (Hall ve Mitchell, 2002: 83). Yeni iş imkânlarının oluşmasını sağlayarak, kırsal ekonomiyi canlandirır.

Bunlara ek olarak gastronomi turizminin destinasyonların sürdürülebilirliğine katk1 sağladığ1 görülmektedir (Yurtseven ve Kaya, 2011:264). Gastronomi var olan turizm sezonunu uzatabilir (Kesici 2012:33; Wan ve Chan, 2013:227). Gastronomi turizmi etkinlikleri, diğer turizm faaliyetlerinden farklı olarak yıl boyunca yapılabilir. (Richards, 2002), yıl içinde çeşitli zamanlara yayılarak yapılacak etkinlikler ile turistler için her dönem cazibe oluşturabilir. Gastronomi turizmi deniz, kum, günes turizminden yararlanamayan destinasyonlar için oldukça önemlidir, hava durumundan etkilenmediği için alternatif olarak yıl boyu yapılabilir (Lopez-Guzman ve SanchezCanizares 2012: 242).

Ayrıca gastronomi turizmi sosyal açıdan da birçok katkı sağlayabilmektedir. Başka bir kültürü tanımanın en kolay yolu, o bölgenin kültürel değeri olan yemeğini tecrübe etmektir. Yemek, küreselleşen dünyada kültürel farklılığı ortaya çıkaran unsurlardan biridir. Yiyecek ve içeceklerin hazırlanması, kültürel kimliğin önemli bir parçasıdır (Aslan ve diğ, 2014:5). Bugün gastronomi turizmi kültür turizminin bir parçası olarak kabul edilmekte, başka kültürlerle bağ kurmak için ve kişilerin kendi kimlikleriyle bağlarının güçlendirmek için kullanılmaktadır (Santich, 2004).

Turistler, yaşayan kültürü deneyimleme ve inceleme firsatı bularak tatillerini zenginleştirmektedir. Ülkeler eşsiz gastronomik lezzetleri, destinasyonlar için tanıtım aracı olarak kullanılmaktadır (Okumuş vd. 2013). Kaliforniya'da Napa Vadisi, Fansa da Provence, İtalya'da Tuscany, Avustralya'da Yarra Vadisi bu bölgelere örnek verilir.

Bir bölgede gastronomi turizmiyle yerel halk bölge gastronomi kültürü hakkında daha fazla bilinçlenmeye başlamaktadır, gastronomi ürünlerinin eşsiz oluşuyla gurur duymakta ( WFTA, 2018),bu da gastronomik ürünlerin unutulmasının önüne geçmektedir. Gastronomi turizmin geliştirilmesinde önemli olan; yerel halkın, yerel ürünleri benimsemesidir (Tüfekçi vd., 2016). Sosyo kültürel mirasa sahip çıkılması, özendirilmesi, bölgenin kültür mirasının korunarak geliştirilmesi ve gelecek nesillere aktarılması için gastronomi turizmi oldukça önemlidir.

Turistlerin yerel mutfağa olan merakı sonucunda, yerel halk ile kaynaşması toplumsal memnuniyet sağlamakta böylece kültürel paylaşımlar gerçekleşmektedir. Gastronomi turizmi ile sosya-kültürel değerlerin korunmasına ve sürdürülmesine katkı sağlamaktadır (Hjalager ve Corigliano, 2000; Yüncü, 2009). Bekar ve Belpınar (2015) yaptıkları çalışmada turistler, yöresel lezzetleri tadarken gürültüden uzaklaştıklarını, yöresel lezzetleri tüketmenin kendilerini daha sağlıklı yapacağına inandıklarını ve bu ürünlerin besleyici olduğunu düşündüklerini belirtmiştir. 


\section{Türkiye'de Turizm Tanıtım Faaliyet ve Stratejileri}

Türkiye'de turizm olgusunun geçmişi 19.yüzyılın ilk yarısıyla başlamış, Cumhuriyet ile birlikte kurulan kurumlarla devam etmiş, 1963 yılında Turizm Tanıtma Bakanlığı kurulmuştur. 1982 yılında çıkarılan 2634 sayılı Turizm Teşvik Kanunu ise önemli bir gelişme olmuştur(TGM Bülten, 2015:5)

1963 ’te planlı kalkınma dönemine girilmesiyle tanıtıma önem verilmeye başlanmıştır. 2018 yılına kadar on adet beş Yıllık Kalkınma Planı hazırlanmıștır. İlk yedi kalkınma planında turizmde tanıtım konusuna çok az yer verildiği görülmektedir. Ağırlıklı olarak gelecek turist sayısı, turizm gelirleri ve yatak kapasiteleri konuları üzerinde durulmuştur. Sekizinci kalkınma planı öncesinde hazırlanan "Tanıtma Özel ihtisas Raporu" ve dokuzuncu beș yıllık kalkınma planı öncesinde hazırlanan "Turizm Özel İhtisas Raporu ile turizm sektörü ayrıntılı ele alınmış ve hedefler konulmuştur. Kalkınma planlarında konulan hedeflere yapılan etkin tanıtım ve pazarlama çalışmaları sayesinde ulaşılarak hedefler aşılmıştır. Kültür Bakanlığı tarafından belirlenen tanıtım stratejileri dört başlık altında toplanmıştır (Aksungur, 2008:87):

Dinamik dış tanıtım: Pazarın değişen şartları sürekli izlenirken, internet başta teknolojilerinin kullanılması bir zorunluluk haline gelmiştir.

Pazar çeşitlendirilmesi: Türkiye'nin yöneleceği "klasik", “yeni” ve "potansiyel” pazarlar belirginlik kazanmıştır. Tanıtım ve pazarlama faaliyetlerine kaynak ayırırken, önceliklerin ve tercihlerin bu pazarlar dikkate alınarak belirlenmesi gerekir.

Y1l boyu talep yaratılması, talebin dengeli dağglımı: Dış pazarlarda değişen tüketici tercihleri dikkate alınarak turizmin çeşitlendirilmesine yönelmek, iç ve dış talep dengesinin bölgelere ve ürünlere dengeli dağılımını sağlamak gerekmektedir.

Eşgüdüm ve işbirliği: Tanıtma ve pazarlamanın daha dinamik, daha profesyonel ve mali yönden daha güçlü yapılabilmesi için, bu maliyetlerin finansmanına turizmden doğrudan veya dolaylı kazanç sağlayan kesimlerin (sektör, yerel yönetimler) katılımları sağlanmalı iletişim ve koordinasyon üst düzeyde olmalıdır.

Ülke tanıtım faaliyetlerinde, ulusal ve uluslararası pazarda net bir imajın ortaya konulması, bölgesel ve yerel turizm imajının oluşturulması, pazarlama faaliyetlerinde bir bütün halinde hareket edilmesi ve bölgesel değerlerin ön plana çıkarılması ile destinasyonların marka haline getirilmesi ön plana çıan konulardır (TGM Bülten, 2015:5) Tanıtım mikro, makro ölçekli olarak özel sektör ve devlet tarafindan yürütülmektedir. Türkiye'de turizmin gerekliliği ve sağladığı faydalar geç görüldüğü için tanıtım faaliyetlerinin önemi anlanmakta gecikilmiştir. Geleneksel Türk konukseverliği ile yıllarca birç̧ok işin halledildiği düşünülmüştür. Türkiye'nin uluslararası turizm piyasasındaki en önemli sorunlarından birisi turistik ürünlerini ve turizm potansiyelini turizm pazarlarına yeteri kadar duyuramamış olmasıdır (İçöz, 1990; 69).

Turizmden pay alan ülkelerin yapmış oldukları bilimsel araştırmalara dayanan tanıtma kampanyaları önemlidir, bir yeri ziyaret etmeye yönelten, potansiyel turizm talebini harekete geçiren şey, onların sahip oldukları güdüler kadar, zihinlerde oluşan ya da oluşturulan objektif ve sübjektif gerçeklere dayanan imajlar ve tanıtma kampanyalarıdır (Tolungüç, 2000: 44).

“Türkiye Turizm Stratejisi 2023" 02.03.2007 tarihinde Resmi Gazetede yayınlanarak yürürlüğe girmiştir. Bu stratejinin hedefi Türkiye'nin doğal kültürel, coğrafi ve tarihi değerleri korunarak, turizm alternatiflerini gerçekleştirerek Türkiye'nin turizmden alacağı payın arttırılmasıdır. Amaç turizm sektörünün önüne bir yol haritası koymaktır.

Türkiye'nin 2023 yılı turizm stratejisi içinde turizm tanıtım ve pazarlama alanındaki hedefleri şu şekildedir:

www.turkishstudies.net/social 
1. Varış yeri odaklı, ürün üstünlüğünü ve toplam kaliteyi öne çıkarmak, markalaşmayı ve marka bağl1lığı sağlayan, hedef kitleye yönelik ürünleri ön plana çıkararak turist sayısının ve turizmden elde edilen gelirin arttırılmasını sağlamak.

2.Akdeniz çanağındaki diğer varış noktalarından farklılık ve üstünlüğün etkin tanıtım ve pazarlama ile markaya bağ lilığ sağlamak.

3.Teknolojik gelişmelerden yararlanmak, uluslararası başarılı kişilerden yararlanmak, ürün çeşitlendirmesiyle üst gelir turist gruplarına ulaşmak ve fuar, ağırlama gibi etkinliklere önem vermek, halkla ilişkiler faaliyetleriyle desteklenen reklam kampanyaları yürütmek, elektronik ortamdan daha fazla yararlanmak.

4.Avrupa ülkelerinde Pazar payı sürdürülebilir turizm ürünlerinin tanıtımı ile arttırılması hedeflenirken, turizm açısından hızla büyüyen Doğu Asya Pasifik(Çin ve Hindistan), Ortadoğu ülkeleri (İran) ve Orta Asya'daki Türk Cumhuriyetlerinde tanıtıma ayrı önem vermek.

5.Her yıl turizmden elde edilen gelirin yüzde 1'nin tanıtıma ayrılarak turizm pazarından daha fazla pay almak hedeflenmektedir. Devletin tanıtım için özel sektöre finansman desteği vermesi, devletin koordinatörlüğünde özel sektörün uygulayıcı olması yeni bir yaklaşımdır. E-tanıtım, epazarlama ve e-ticaret gibi gelişmelere kamu ve özel sektörde yatırımlar yapılacaktır.

6.Turizmi etkileyen terör olayları, insan hakları ve demokrasi gibi konularda negatif yayınların oluşturduğu olumsuz imajın düzeltilmesi için proje ve programlar hazırlamak.

Planlanan çalışmalar istenilen düzeyde gerçekleşirse 2023 y1lı hedefinde Türkiye'nin 63 milyon turist ve 86 milyar dolar dış turizm öngörüsü bulunmaktadır (kultur.gov.tr, 2018).

\section{Tanıtım ve Pazarlamada Gastronomik Değerler}

10 Ekim 2017 tarihinde Gastronomi Turizmi Komisyonu Ön Hazırlık Toplantısında ve 1-3 Kasım 2017 tarihleri arasında yapılan Turizm şurasında Türk Gastronomisi ön plana alınmıştır. "Tanım, Kapsam, Vizyon ve Strateji”, "Ürün", "Eğitim", "Tanıtma-Pazarlama”, "Örgütleme, Koordinasyon ve Eşgüdüm”, "Tesisler, Belgelendirme ve Teşvik" başlıkları altında karalar verilmiştir. Öncelikli amaç olarak gastronomi kültürünün çağdaş anlamda bir ürün olarak kabul edilerek, geliştirilerek dağıtım kanalları aracılığıyla küresel pazarda sunulacak biçimde tasarlaması gerektiği kabul edilmiştir. Türk gastronomisi kavramını kullanılarak, çalışmaların coğrafya temelli yürütülmesi hedeflenmektedir. Türkiye turizminin uluslararası tanıtımında gastronomi turizminin taşıdığı stratejik önemden dolayı Türkiye Turizm Stratejisi 2023 belgesine ayrı bir başlık olarak ilave edilmesi belirtilmiştir.

Tanıtım ve pazarlama başlığı altındaki alınan kararları şunlardır; (turizmsurasi.kulturturizm.gov, 2018)

1. "2023 Türkiye Turizm Stratejisi”ne dâhil edilmesi teklif edilen gastronomi turizmine ilişkin maddelerde tanıtım ve pazarlama anlayış ve faaliyetlerine ilişkin genel çerçeve ve prensiplerin oluşturulması gerekmektedir. Tanıtma ve pazarlama faaliyetleri çerçevesinde; verilmesi;

a) Gastronomiyle ilişkili UNESCO 'Somut Olmayan Kültürel Miras' değerlerine önem

b) Her şey dâhil sistemde hizmet veren işletmelerdeki geleneksel Türk mutfağı sunumlarının orijinal şekilde yapılması; bu işletmelerin menülerinde geleneksel ve yöresel Türk mutfağ 1 alternatiflerine yer verilmesine, mevcut menülerdeki seçeneklerin bu doğrultuda arttırılmasına dikkat edilmesi yönünde çalışmalar yapılması; 
c) Kurulması teklif edilen "Türkiye Gastronomi Kurumu"nun sinıflandırma, derecelendirme ve ölçmeden sorumlu çalışma grubunun önereceği kaliteli, temiz, sağlıklı ürün sahibi esnaf ve zanaatkârların tüm gastronomi etkinliklerine katılımının teşvik edilmesi;

d) Gastronomi turizminin ülke içinde de düşünülerek Türk mutfağının aranan, istenilen, iftahar edilen bir unsur haline getirilmesi için girişimlerde bulunulması;

e) Dışarıda yeme-içme alışkanlığının iç pazarda da özendirilmesi ve arttırılması için çalışmalar yürütülmesi;

f) Yabancı şef, gazete ve blog yazarları ve marka elçilerinin Türk gastronomisini görmeleri için davet edilmesi ve ağırlanması;

g) Gastronomi turizmini geliştirmek ve ön plana çıkarmak amacıyla düzenlenen ulusal ve uluslararası resmi kutlamalar, özel günler, yarışmalar, organizasyonlar, gösteriler, konferanslar, forumlar, workshoplar, sergiler, fuarlar ya da bazılarının bir araya getirilmesiyle tasarlanan etkinlikler düzenlenmesi;

h) Sergiler, müzeler ve benzeri etkinlik organizasyonlarının özgün senaryolar ve çağdaş müzecilik anlayışıyla uzmanlar tarafindan oluşturulması;

i) Büyük şehirlerde gastronomi ve eğlence turizminin kültür ve ekonomik seviyesi yüksek turistlerle buluşması amacıyla , moda, sanat, tasarım vb. etkinliklerle entegre edilmesi;

j) Turistlerin yoğun oldukları destinasyonlarda tarihi han, çarşı ve pazarlarda yerel, kaliteli ve iyi gastronomi ürünlerinin bulunması için çalışmalarda bulunulması;

k) Gastronomik etkinliklerde ve uluslararası dijital platformlarda gösterilebilecek Türk gastronomisi ile ilgili film, belgesel vb. projelerin, Bakanlıkça verilen sinema desteklerinden yararlandirılması.

2. Yapılan tanıtma ve pazarlama çalışmalarında, belirlenen hedef gruba; televizyon ve radyo, billbord, ve yazılı basın gibi geleneksel tanıtım alanlarındaki, yapılan çalışmaları destekleyen reklamlar ve tanıtım faaliyetleri gerçekleştirilmeli; dijital platformda ise sosyal medya (, Facebook, Twitter, Instagram, Youtube vb.) ve internete yönelik içerikler geliştirilmelive mobil uygulamalar hazırlanmalır.

\section{Yöntem}

\section{Araştırmanın Amacı Ve Yöntemi}

$\mathrm{Bu}$ çalışmada Türkiye turizm tanıtım faaliyetlerinde gastronomik değerlerin kullanımının önemi, neler yapılabilineceği ve Türkiye'de gastronomi turizminin durumunu belirlenmeye çalışılmıştır. Bunun için görüşmecilere aşağıdaki sorular yöneltilmiştir:

- Türkiye'deki gastronomi turizmini nasıl değerlendiriyorsunuz?

- Türk mutfağının dünyanın en önemli üç mutfağı arasında olduğu sizce yeterince bilinmekte midir?

- Türk mutfağı sizce yurt dışında nasıl temsil ediliyor?

- Tanıtım faaliyetlerinde kullanılan gastronomik değerler nelerdir?

- Katıldığınız etkinliklerle ilgili görüsslerinizi ve gözlemlerinizi aktarabilir misiniz?

- Diğer ülkelerle kıyaslandığında ülkemizi nerede görüyorsunuz?

- Sizce başarılı ülkeler hangileridir? Güçlü yönleri nelerdir, kıyaslayabilir misiniz?

- Etkin bir tanıtım faaliyetinde Türk mutfağının hangi ögeleri ön plana çıkartılmalıdır?

- Coğrafi işaretli ürünlerin, Unesco Gastronomi şehirlerinin ve her şey dahil sistemin Türk gastronomisi üzerindeki etkileri sizce nelerdir? 
- Gastronomi turizminden daha fazla pay alabilmemiz için neler yapmalıyız?

- Türkiye'de gastronomi turizmi için yapılacaklar için yetki sizde olsa önceliğiniz ne olur, önerileriniz nelerdir?

$\mathrm{Bu}$ bağlamda, çalışma tespitine betimsel bir nitel araştırma olarak tasarlanmıştır. Nitel araştırmanın tümevarımsal bir yaklaşım oluşu, belirli durumlara ve kişilere odaklanması ve ifadeler üzerinden değerlendirme yapılmasına imkan vermesi nitel çalışmaların en güçlü yanlarıdır. Nitel araştırmalarda en çok başvurulan yöntemlerden biri görüşmedir. Bu çalışma için derinlemesine görüşme yöntemi kullanılmıştır. Derinlemesine görüşme açık uçlu, keşif odaklı, görüşmecinin duygularını ve bakış açısını derinlemesine keşfetmeyi amaçlayan bir metottur (Baş ve Akturan, 2017). Buradan hareketle çalışma için Türk mutfağı ve gastronomi turizmi konusunda bilgili kişilerle yarı yapılandırılmış görüşmeler yapılması planlanmıştır.

\section{Araştırmanın Örneklemi}

Araştırma kapsamında uzman kişiler belirlenirken, nitel araştırmalarda kullanılan amaçlı örneklem türlerinden olan kartopu örneklem yönteminden faydalanılmıştır. Kartopu örneklem yöntemi, katılımcılardan yoğun ve önemli bilgilerin edinildiği bir örneklem yöntemidir. Nitel araştırmalarda örneklemin geniş olması her zaman mümkün olmamaktadır. $\mathrm{Bu}$ araştırmada örneklemi Türk mutfağı konusunda uzman olan araştırmacıları, aşçılar, ve akademisyenler oluşturmaktadır.

Öncelikle konu ile ilgisi olduğu düşünülen iki kişiye Ankara'da düzenlenen bir gastronomi etkinliğinde ulaşılmış, kendileriyle yüz yüze görüşülmüştür. Bu kişilerin yönlendirdiği kişilerden bir liste oluşturulmuştur. Telefon ile görüşülerek çalışmaya gönüllü olarak katılım sağlayıp sağlamayacakları sorulmuştur. Katılım için olumlu yanıt veren kişilerle bireysel görüşmeler sırasında, bu görüşmeciler diğer uzman kişilere yönlendirmeler yapmışlardır. Kartopu olarak adlandırılan yöntemle ilgili kişilere ulaşılmıştır.

\section{Verilerin Toplaması ve Analizi}

Araştırmada yarı yapılandırılmış görüşme formu kullanılmıştır. Nitel araştırmalarda yaygın kullanılan bu yöntem, önceden belirlenmiş sorular ya da görüşme sırasında ortaya çıkan konulara göre yeni sorularında sorulabilmesi şeklindedir. Görüşmelere göre gereksiz soruların çıkarılmasına ve yeni sorular eklenmesine imkan veren esnek bir yapıdadır (Güler, Halıcıoğlu ve Taşğın, 2013). Görüşme soruları belirlenirken ilgili literatürden yola çıkılarak, araştırmanın amacına uygun sorular olmasına dikkat edilmiştir. Görüşmecilere, Türk mutfağının mevcut durumu, sorunları, mutfaklarıyla öne çıkan ülkelerin yaptıklarının değerlendirilmesi, hangi konularda eksikliklerin olduğu ve neler yapılabileceği ile ilgili sorular yöneltilmiştir.

Araştırma için Şubat ve Nisan 2019 tarihleri arasında toplam 10 kişi ile görüşmeler gerçekleştirilmiştir. Elde edilen veriler ile istenilen doygunluğa ulaşılmıştır. Görüşmeler öncesinde katılımcılara kimlik bilgilerinin gizli kalacağı belirtilerek, ses kaydı yapmak için izin istenmiştir. Ses kaydı ve notlar alınarak, görüşme sonrasında veriler elektronik ortamda yedeklenmiştir. Görüşmeler 30-65 dakika arasında uygun ortamlarda gerçekleştirilmiş̧tir. Bireysel görüşmelerin ardından her görüşmenin ses kaydının transkripsiyonu yapılmış, dijital ortama aktarılmıştır. Katılımcılara iliş̧kin bilgiler incelendiğinde araştırmaya katılanların 5'i erkek 5'i kadınlardan oluşmaktadır. Eğitim durumlarında ise katılanların 3'ü yüksek lisans mezunuyken 7'isi de lisan mezunudur. Katılanların mesleklerine göre dağılımları incelendiğinde katılanların 5'i şef/eğitmen şef, 2'si Akademisyen şef ve 1'er kişi de Turizmci/Dernek Başkanı, Arkeolog/Marka Uzmanı ve Mutfak Araştırmacısı/Isşletmeci olarak çalışmaktadır.

Görüşmelerden elde edilen veriler betimsel olarak analiz edilmiştir. Betimsel analiz, görüşülen veya gözlenen bireylerin ifadelerini doğru biçimde yansıtmak amacıyla doğrudan alıntılar 
kullanılmasıdır. Bu araştırmada geçerlilik kriterini sağlamak adına; a) görüşme yöntemleri ile ilgili kaynaklar taranmıştır. b) Tecrübeli kişilerden görüş alınmış, sorular kontrol ettirilmiştir. c) Katılımcılardan alınan bilgilerde doygunluğa ulaşılıp tekrar etmeye başlanıldığında çalışmaya son verilmiştir. d) Katılımcıların cevapları doğrudan alınarak yorumlanmıştır.

Çalışmanın güvenilirliği içinse, a) Görüșmecilere aynı sorular sorulmuștur. b) Tüm görüşmeler ses kayıt programı ile kayıt altına alınmış, elektronik ortamda yedeklenmiştir. c) Konu dışındaki yapılan aktarımlar ve politik açıklamalar veri analizinde ayıklanmıştır. d) Verilerin analizi için görüşmeler tekrar tekrar gözden geçirilerek okunmuştur.

\section{Bulgular}

\section{Türkiye'de Gastronomi Turizminin Mevcut Durumu}

Katılımcıların görüşleri doğrultusunda Türkiye'de gastronomi turizmi değerlendirilirken tespit edilen hususlar kategorilere ayrılarak ayrıntılı şekilde sunulmuştur.

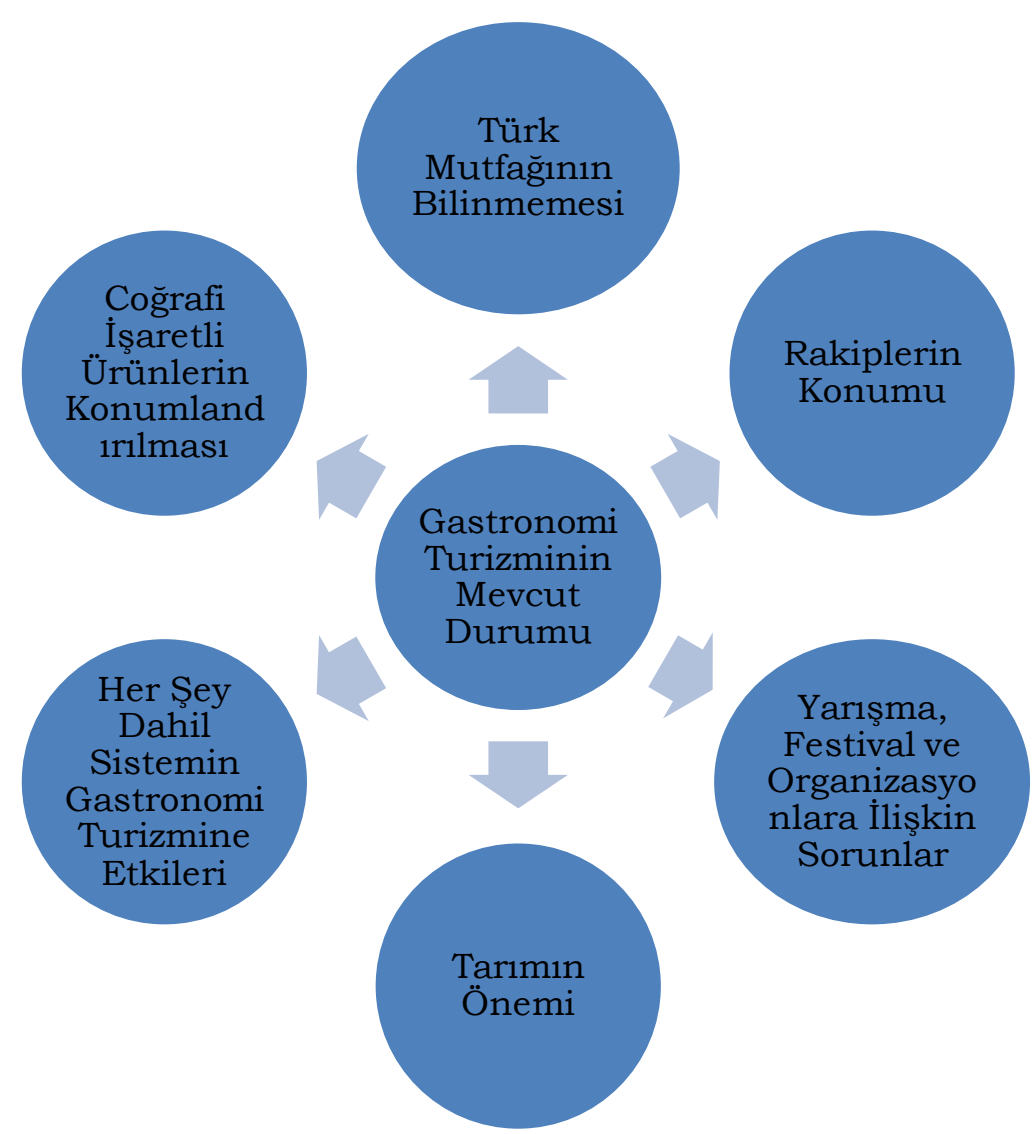

Şekil 1. Türk Gastronomisinin Mevcut Durumu ve Sorunlar

\section{Türk Mutfağının Bilinmemesi}

Türk mutfağının Fransız ve Çin mutfaklarıyla birlikte dünyanın en önemli üç mutfağından birisidir görüşü hakkında katılımcıların fikirleri alınmıştır. Yurtdışında farklı ülkelerde çalışan, yarışmalara ve etkinliklere katılan, dünyanın birçok yerine seyahat eden katılımcılar mutfağımızın 
zengin bir mutfak olduğunu ama tanıtılmadığ K7 nolu katılımcılar şu şekilde ifade etmektedirler.

“Mutfağın zenginliği tartışılmaz. Çünkü Anadolu, yüzyıllara dayanan toprağın üstündeyiz. Anadolu dediğimiz bölgede sadece Türkler değil, önceki birçok devlette bu topraklarda bu kültürü zenginleş̧irmiş̧ir. Dolayısı ile zenginliği ile ilgili bir sıkıntı yok ama tanınırlı̆ğ ile ilgili ciddi sıkıntılarımız var. Bizim Ege bölgesi beslenme tarzı ile ilgili Unesco'ya giren ülkeler var ama bunların içerisinde Türkiye yok. Ciddi bir sıkıntı. Bu da bizim sıkıntımızı çok net gösteren bir şey, ürünlerimiz bölgesel il, il çok zengin, çok fazla ama...” (K6)

"Türk topraklarından o kadar fazla kültür geçmiş, o kadar çok ürün çeşitliliği var, hakikaten çok zengin mutfağımız var. Bu zenginlik ile dünyanın birinci, ikinci, üçüncü olma şansı var. Ama yeterince tanitılmadı ̆̆ için yeterince arkasında durulmadığ iç̧in maalesef dünyanın üçüncü mutfă̆ değiliz. Öyle bir şey yok ama zenginliği güzel kullanabilirsek her türlü ilk üçe girebileceğimiz inancindayım." (K7)

Türk mutfağının birçok uygarlığa ev sahipliği yaptığı ve farklı halkların kültürlerinden etkilendiği K2 ve K5 nolu katılımcılar tarafindan şu sözlerle paylaşılmıştır.

“...Türk mutfă̆ı çok iyi bir geçiş mutfağıdır. Bize gelen özel ürünleri çevirip dünya mutfaklarına kendi damak zevklerine uygun hale getiren bir katalizör gibiyiz, o yüzden biz çok kalıcıyız.... Ben Türkiye'yi yurt dışında temsil ettim, yarışmaya katıldım ve çok zorluklar yaşadım. Yarışmada birincilik ödülü aldım ama benim en çok zorlandı̆̆ım şey mutfağı bilmiyor olmalarıydı, her yerde olduğu gibi siyasi politik etkenler çok önemli... Ben Türk mutfağını anlatırken çok zorlandım, Ortadoğu ile aynı tarafa koymuslardı sunum masamı ama ben ısrarla sunum masamın Avrupa ile Asya arsında olması gerektiğini anlatmaya çalıştım. Nedeni denilince, o noktada sizin bilginizin çok ön planda olması gerekiyor. Kültürümüzün bilgi olması gerekiyor." (K2)

"Türk mutfă̆ı dediğimiz zaman 600 ylllık bir Osmanlı kültürü var, bu kültürde yaşayan Ermeniler, Rumlar, Museviler Türk mutfağının içine giriyor. Çerkesler, Arnavutlar var, Araplar da giriyor baktığımız zaman, çok kültürlü mutfağa sahibiz. Osmanlı, 25 milyon metrekareye kadar ulaşan topraklarda yaşayan, çok değişik milletlerin mutfak kültürleri var. Bu kültürler birlikte yaşadı ve mutfakları birlikte kulland, mutfaklar birbirine geçti....13.000 yıl öncesinin buğdayı bizim topraklarımızda. Dört mevsim yaşandı ̆̆ için ürün çeşitliliği bol, dünyanın ilk zeytinyağı üretim tesisi 5000 yıl öncesinde Diyarbakır'da... Maalesef bunu sadece biz biliyoruz.. "' (K5)

Türk mutfağının bilinirliğini ölçmek için K1 ve K3 nolu katılımcılar yaptıkları araştırmaların sonuçlarını görüşmeler sırasında aşağıdaki şekilde paylaşmışlardır.

"Bana göre Türk mutfă̆ dünyanın bir numaralı mutfă̆g. Fakat bilinmede 44.cüyüz. Biz bir araştırma yaptırdık. Beş şehirde ve yurt dışında bazı ülkelerde. Türkiye bilinmiyor. Çin mutfağı, İtalyan mutfă̆ biliniyor. Türk mutfăğ bilinmiyor. Bu ilk üç mutfağ dayanmıyor. Biz algıla 44.cüyüz... Dünya tek bir platform aslinda, ülkeler, sinırlar ama Türk mutfağı dediğimizde 12.000 yıl öncesine nasıl dönüyoruz. Anadolunun tüm lezzetleri içinde. Sinırlar aslında kalkmış durumda ama Anadolu dünyanın merkezi. O yüzden bizim ürünümüz kalibremiz dünyada yok. İtalya'ya gidip beş çeşit şey yiyorsunuz. Bizim 330 çeşit bulgurdan yapılan yemeğimiz var." (K1)

Ben bunun anketini yaptım. Bă̆dat caddesinde 5000 kişiye sordum sekiz günde, Türk mutfă̆ını tanıyan yüzde üç.... Fransa'ya gidin Türk mutfă̆ını sorun, İtalyan mutfağını sorun. Size Türk mutfağından baklava, kebap, döner, lahmacun, çiğ köfte söylerler.” (K3)

Türk mutfağının bilinmemesinin en büyük sebebi olarak mutfağın tanıtılmaması ve pazarlanması olarak görülmektedir. Konuyla ilgili görüşlerini K1,K4, K9 ve K10 nolu katılımcılar aşağıdaki şekilde dile getirilmiştir.

Turkish Studies - Social, 15(2) 
"Türkiye'de gastronomi turisti 295 dolar harclyor, bizim bunu 1000 dolar yapmamız gerekiyor. Michelin yıldızlı bir restoran tabağı için 100 euro ödüyorsun. Bizim satıs rakamlarımız çok aşă̆ılda kalıyor. Ama bu tanitımla alakalı....”(K1)

"Dünyanın en önemli üç mutfağından birisidir cümlesini, dünya bu cümleyi kurmuyor, onlar söylemiyor bunu... Türk mutfağına ilgi var, doğru tanttım yapılan her yere ilgi olur. Doğru lanse edilirse, bilinen bir mutfak ama pazarlaması bizim elimizde. Herkesin Türk mutfağından, kebaptan, baklavadan, dönerden haberi var, Turkish kebabı dünyanın neresine giderseniz gidin bilmeyen yok, ama Türk mutfă̆ı pazarlanmış değil. "(K4)

"Dünyanın en önemli mutfă̆ından biridir cümlesi ancak arkasında bir marketing olduğu zaman işe yartyor." (K9)

"Avrupalı bizim mutfăğmızı bilmiyor. Bilse, evlerinde pişiriliyor olurdu. Nasıl ki biz Fransız yemeği olan sağan çorbasını, bizim kültürümüzde fazla yok ama soğan çorbası bütün ülke olarak biliyor olduk. Artık yemeklerimizde sos kullanmaya başladık, biz de genelde soslu yemekler yoktur. Biz de genelde tencere yemekleri vardır, soslu yemekler Fransız mutfă̆ındadır. Mutfağın uluslararasılaşması konusunda biz biraz zaylfiz. Biz hala dönerin, baklavanın Yunan olmadı̆̆ konusunda, başka bir deyişle kendi ürünlerimize çok fazla sahip çıkmayan bir kültürdeyiz. Yoğurdu dünyaya yayan Türklerdir ama Greek yoğurdu olarak satıllyor. Avrupa'nın birçok yerine gittiğim için söylüyorum." (K10)

\section{Rakiplerin Konumu}

Dünyada gastronomisiyle öne çıkan birçok ülke bulunmaktadır. İspanya, İtalya, Fransa, Çin ve Japonya bugün gastronomi turizmi denilince ilk akla gelen, başarılı ülkeler olarak bilinmektedir. Katılımcılar bu mutfakların dünyaca ünlü mutfaklar olduğunu, ve dünyanın birçok şehrinde bu mutfaklara ait ürünlerin ve restoranların olduğunu belirtmişlerdir. Bununla birlikte Peru, Tayland ve Lübnan mutfakları da görüşmecilerin, dikkat çektikleri mutfaklar olarak karşımıza çıkmaktadır.

K7 nolu katılımcı: "Çin'in en önemli mutfaklardan biri olmasının en önemli nedeni devletin desteğinin olması, gastro diplomasi adı altında göstermeleri, tanıtmalarıdır. Bunu Çin bitirdi, hangi ülke yapıyor derseniz Peru, çok güzel örneği. Peru gastronomi diplomasisi altında dünyanın her yerinde, Bodrum da bile bir restoranı var. Peru'dan aşçı getiriyor....Devleti arkaya almak lazım, devlet ile beraber ilerlememiz lazım." cümleleriyle ülke mutfakları için gastro diplomasinin önemine değinmiștir.

Yine Amerika'daki gastronomi turizmi ile ilgili katılımc1 K6: "Amerika aslinda fastfood olarak görülüyor ama fine dining dediğimiz üst segment restoranlar çok destekleyen, çok iyi örneklerin olduğu, gastronomi etkinliklerinin çok fazla yapıldı ̆̆ bir ülke”, K8 nolu katılımcı ise: “... sonradan gelen Avustralya hepimizden başarıll, çok iyi gidiyor, hiç beğenmediğimiz Güney Afrika mutfă̆ı iyi gidiyor" diyerek diğer ülke mutfaklarına da dikkat çekmişlerdir.

\section{Yarışma, Festival ve Organizasyonlara İlişkin Sorunlar}

Gastronomi turizmini geliştirmek ve ön plana çıkarmak için düzenlenen yarışmalar ve çeşitli organizasyonların amacına uygun sonuçlar verip vermediği tartışılmaktadır. Birçok organizasyonun yapılması kaynak ve zaman israfina yol açmaktadır. Düzenlenen aşçı ve yemek yarışmalarının gastronomi turizmine etkileri K6 ve K10 nolu katılımcılar tarafından şu şekilde anlatılmaktadır.

"Yarışmalar tanıtımda ne kadar aktif rol oynuyor, bu benim kafamda hep soru işareti olmuştur. Yurt dışına giden her şef bir tanıtım elçisi. Yurt dışına gittiğiniz zaman bir İtalyan yemeği yapmaktansa, gerçek bir Türk yemeği yapmak, bir çorba yapmak ufak, ufak etkisi olacak tanttım çalışmalarıdır. Dolayısıyla giden kişilerin bu yönde bilinçlenmesi gerekiyor.... O kadar çok yarışma var ki, çocuklar sürekli oradan oraya koşturuyor...tek başına yarışmalar, birazcık ucu kaçtı, ne tanitıyoruz ki yarışma ile. "(K6) 
"Yarışmalar amacına ulaşmıyor, büyük yarışmalar dışında. Antalya Altın Kep vardl, uluslararası yarışma, Alanya'da Altın Kepçe. Eskiden Ankara'da Şef8 yapılırdı. Bence ülkenin en büyük yarışması, International İstanbul Culinary Cup 2019 yapllacak, ben de gideceğim. Bunun bütün dünyada tanıtımı yapılabilinir, ses getirebilir. Yoksa x ilçesinde yapığımız küçük çaplı yarışmalar sadece oradaki gençleri motive eder, Bu da önemlidir, gelir madalya alır, eksiklerini görür. Ama büyük kısmı dersen ülkede uluslararası tanınan dünya şefler birliğinin tanıdı ̆̆ bir yarışma şu ana kadar kan kaybettik. Şu anda öyle bir yarışmamız yok. İstanbul da yapılacak olan, üst düzey, ülkede gastronomi adına büyük şefleri bir araya getiren bir yarışma olacak.” (K10)

Gastronomi aktivitelerine katılmak için gelen ziyaretçiler için festivaller ve gastronomi organizasyonları vazgeçilmezdir. Festivaller turistlerin birçok yerel tat ile buluşmasını sağlamaktadır. Katılımcılardan K6: “...festivaller il bazında, ilçe bazında çok keyifli ama uluslararası arenaya çıkartmak için devletin tecrübesi ve öngörülerinden faydalanmak gerekiyor. Zenginliğimiz bizim şansızlığımız olmaya başladı, çok fazla ürün var. Iyi tahlil ederek birkaç tane ürüne uluslararası anlamda ön plana çıkarmak için destek verebilir, onlar dikkatleri çektikten sonra başka ürünler desteklenebilir. Hepsini aynı anda promote etmemiz, tanıtım çalışmaları gerçekleştirmemiz sanırım kaynak anlamında ve verimlilik anlamında da mümkün değil." cümleleriyle bazı festivallerin tanıtım için daha ön plana çıkarılması gerektiğini belirtmiştir.

Yapılan etkinliklerle dünyaca ünlü şeflerin ülkemize gelmeleri de onların yöresel ürünler ve farklı mutfak kültürleri ile tanışmalarını sağlamaktadır. Michelin yıldızlı şeflerin tanıtım organizasyonlarına gelmeleriyle ilgili olarak K8 nolu kat1lımc1: Michelin yıldızl restoranlara biz ögrenci gönderemiyorduk. Bizim vize sorunumuz var. Çocuğumuz oraya gittiği zaman 90 gün kalıyor, seni çok beğendik kal deseler kalamazlar. Ne zamanki gastronomi organizasyonları yapılmaya başlandı, bizim öğrenciler onlarla tanıştılar, stajer olarak kabul edildiler. Bizim çocuklar, Michelin ylldizlı restoranlara gitmeye başladılar. Çok ciddi vize sorunu var. O restoranlardan birindeki ögrencimiz gitti, çalışıyor şimdi. Kendi ülkenden, yörenden bir yemek yap demişler. $O$ da kerebiç tatllsı yapmış, Antakyalı olduğu için. Çok ilgilerini çekmiş, çok merak etmişler. Çok önemli böyle organizasyonların olması" görüşüyle bu organizasyonların olumlu etkilerini ve gelişmeleri paylaşmıştır.

Türkiye'de yurt dışından gelen şeflerle yapılan organizasyonların Türk mutfağını tanıtmak için bir etkisi olmadığını belirten K1, K7 ve K9 nolu katılımcılar görüşlerini şöyle açıklamaktadırlar.

"Tanıtım stratejisinde şu yok. Medya planlaması yok. New York'ta, İtalya'da ne yapacağız, bu yok. El yordamıyla. Ankara'da değil, bunu San Sebastian da yapmamız gerekiyor. ”(K1)

“....Türk mutfağını da Türkiye’yi de tanıtmıyoruz gelen Türk mutfă̆ını yüzde yirmi tanınıyorsa, aş̧̧ı yüzde seksen tanınıyor. Onun için yapmamız gereken kadrolaşıp, yurt dışına gidip oralarda yemeğimizi yapmallyız. Tattırmakta değil, böyle bir yere gelemeyiz. Nasıl şu anda evde pizza yapıyoruz, hamburger, makarna yapıyoruz. Aynı şekilde bir Fransızın, Türk olmayan birinin de, bizim yemeklerimizi yapıyor kıvama gelmesi gerekiyor. Bunun için yurt dışındaki büyük elçilikler ile bir organizasyon yapmak istiyoruz. Bir tek yemek yapıp sunmak değil. Haftanın üç günü workshop yapmak, hem yemeğimizi, hem kültürümüzü, hem pişirme tekniğimizi göstermek. Zaten yenildiği zaman beğenilen bir mutfak. Ĕger kişi bunu evinde yapmaya başlarsa severse, ister istemez bu toplumda restoranlarda ortaya çıkıp sunulmaya başlanacak, bu en büyük şey. 3-5 sene sonra 10 sene sonra yurt dışı restoranların içinde şeflerin dokunuşlarıyla yorumlarlyla Türk mutfağını kendi mutfakları ile füzyonladıklarını görmeye başlayacağız." (K7)

“....onlar buraya geliyor ama bölük, pörçük bir şeyler anlatıyorlar. Buradaki kontağı kimse, kontağının vizyonu kadar Türkiye'yi tanıtıyor. Yabancı şeflere ya da Türk şeflerle Türkiye de program yaptırmak ve uluslararası yemek kanallarında yayınlanmasını sağlamak. Baharat yolu ve ipek yolunu anlatan, yemekle ilgili programlar olmal.." (K9) 


\section{Coğrafi İşaretli Ürünlerin Konumlandırılması}

Coğrafi işaretli ürünlerin rekabette ve ülke tanıtımda etkin olduğu bilinmektedir. Tanıtım için coğrafi işaretlerin ön planda kullanılması katılımcılar tarafından desteklenmektedir. Fakat ürünlerin doğru konumlandırılması gerekliği üzerinde durulmaktadır. Katılımcılardan K7: "Coğrafi işaretli ürünlerimiz çok, çok önemli. Bu da bir basamak ama coğrafi işaretli ürünler ile bitmiyor. Şehirde findık heykeli yapıllyor, bayram yapıyor. Orada kallyor. O ürün işlenecek, dünyaya tanitılacak, satabilecek şekilde olmalı." ve katılımc1 K10: "Coğrafi işaretli ürünler ülkemizin tarımını kurtaracak ürünlerdir. Coğrafi ürünler ile aynı kaliteyi ve standardizasyonu yakalayabilirsek ilerleyebiliriz. Coğrafi işaretli ürünler ile, ürünlerimizin kaliteli olduğundan hareketle, standart bir şekilde tanıtıma gidebiliriz." cümleleriyle coğrafi işaretli ürünlerin dünya çapında tanıtılmasının önemini belirtmişlerdir.

K6 nolu katılımc1 ise: "Bu bilincin oluşması çok güzel, ilerliyor süreç. Sadece yavaş ilerliyor. Вu konu, dünyada popüler bizim sabrımı yetmiyor. Ama popüler ülkelerin, popüler ürünlerine baktığınızda yapılan çalışmalar, Türkiye 50-100 yıl geriden geliyor.” ifadesi ile çalışmaların kesintisiz devam etmesi üzerinde durmaktadır. Tanıtım etkinliklerinde bu ürünlerin aktif sunulabilmesi için K4 nolu katılımcı görüşünü şöyle açıklamaktadır.

"Bir dönem Malatya kayısısl, Giresun findı̆̆ paketlenip Türk Hava Yolları seyahatlerinde verildi. Bu tarz şeyleri sürekli yapılip, insanlar oraya gidip görmeye motive edilirse. Aydın inciri, son derece klymetli bir ürün, AB tescilli coğrafi işaretli bir ürün. Tanitıp lanse edilecekken hiç ortalıkta yok. Kendi sahip olduğumuz kültürel miras ile Türk Hava Yollarılla, bir hükümet politikası olsa, her ay bir ürünü koyup, o bölgenin tanitılması ve gidilmesi ile alakalı bilboardlarda, reklamalar olsa. Kevin Costner'a Aydın inciri yedirt, Malatya'ya götür. Kobe Bryant Kayseri cıvılklss yesin. Uçakta şovunu yapsın. Ama gitsin orada onu yesin. Onun çorba içtiği dükkan, yemek yediği restoran, bakın millet oraya nasıl akın ediyor. Bir dünya ve ülke politikası olmadıkça hiçbir şey yapamayız."

\section{Tarım}

Gastronominin topraktan başladığı, turizm politikası ve yiyecek politikalarının birbiriyle olan ilişkisi günümüzde en önemli konulardan birisidir. İyi tarımın yapılması ve kaliteli ürünler elde etmenin önemi K5 ve K6 nolu katılımcılar tarafından şu şekilde ifade edilmiştir.

"Çiftçi desteklenmeli ve doğru tarım yapılmall, sofraya gelen ürün sağglılı ve kaliteli olmalı... Chia tohumu, kinoa, neden biz bulgurumuzu kullanmayalım."(K5)

“Türkiye'nin yemekle ilgili bir sılkntısı yok, müthiş bir zenginlik var ülkemizde. Fakat tarımdaki üzücü gelişmeler, kendi üretimimizi yapamayıp dışarıya bağımlı olmak ve tüketmek benim için çok üzücü. Ürünlerin sezonlarının bulanıklaştığını görmek... Çünkü bir söz var İtalyanların sanırım. Iyi bir tart yapmak için, iyi limonlara ihtiyacınız var. Bu işi yapmak istiyorsak iyi ürünlerimiz olmall. Mutfaklara gelen ürünlerin, üretiminden itibaren bu gerçekten bir ülke meselesi, vatan meselesi olmall, zenginlikler korunmall. Tüm dünyanın yöresel ürünlerin klymetini anladiğ bu dönemde, toplu tüketimden ziyade, butik üretim yapanlara da destek olmamız çok önemli. Sayamayacağımız kadar çok özel ürünümüz var ve bunların desteklenmesi lazım, korunması çok önemli." (K6)

Benzer şekilde K10 nolu katılımcı tarladan sofraya ürünün hikayesinin gastronomi turizminde anlatılmasının önemini şu şekilde ifade etmektedir.

“.... bu iş aslinda ekimden başllyor, üründen başlamall, Kaliteli ürün ürettiğiniz zaman, ülkede belirli reçeteler çıkarı, bunun standardizasyonu üzerine giderim. Öncelikle iyi ürün, iyi ürün aldığımızı varsayarak, belirlenmiş ürünler üzerinden standardizasyon ve sonrada tanıtım, tarladan sofraya hikayesini anlatmamı gerekiyor, çok önemli." (K10) 
Gastronomi turizmi için topraklarımızdaki tarım arazilerinin değerlendirilip, iyi tarımın yapılması ve politik olarak bunun desteklenmesi gerekliliği K4 nolu katılımcı tarafindan şu şekilde paylaşılmıştır: "...çalışma yapıp, bu bir ülke politikası olmadıkça bir ülkede ihracat artmadıkça ve ithalat azalmadıkça, Mezopotamya topraklarında yaşayan toplum tarım yapmadiğı sürece gastronomi turizminin geliştirilmesi çok üzülerek söylüyorum mümkün değildir.” (K4)

\section{Her Şey Dahil Sistemin Gastronomi Turizmine Etkisi}

Turistlerin konaklama yaptıkları yerlerin birer tanıtım mecrası olduğu düşünülerek hareket edildiğinde, bu yerlerde sunulan Türk mutfağı örneklerinin özenli olması gerekmektedir. Türk mutfağı sunumlarının aslına uygun yapılması, geleneksel ve yöresel tatlara doğru şekilde yer verilmesi önemlidir.

Susever (2014) pazarlama iletişimi olarak her şey dahil sisteminin Türk mutfağı tanıtımındaki yerini araştırdığı çalışmasında, her şey dahil sisteminin ülkemiz için bir çıkış yolu olarak işlevini tamamladığını ve Türk mutfak kültürünün tanıtımı açısından fazla katkı sağlamadığını belirtmiştir. Her şey dahil sistemin ülkemizde kullanıldığg şekli ile devam ederse Türk mutfak kültürünün tanıtımını olumsuz etkileneceğini açıklamıştır.

Her şey dahil sistemi ve Türk mutfağı ile ilgili, K4, K6 ve K7 nolu katılımcılar aşağıdaki yorumları yapmıştır.

"Bu sistem gastronomiyi birinci derecede öldürüyor, zamanında popüler diye girildi. Bütün ülkeye yaylldı. 1000 kişinin aynı anda yemek yediği yemekhane usulü son derece çirkin, patates püresinin hazır bir tozdan ve sudan yapıldiğı, insanların ucuz ve bedava yemek yediği bir hale geldi. Bu gastronomi değil, böyle olmaması lazım. Fransız mutfağından örnek veriyorum, sadece Antrikot ve patates servis edilen bir lokanta için insanlar saatlerce kuyruk bekliyor." (K4)

"Her şey dahil otellerde ürünümüzü basitleştiriyor ve ucuz hale getiriyor. Kitle turizmine hizmet etmek rahatsızlık verici bu şekilde. Çok daha özel zaman ve para ayrllabilecek bir ürünümüz var. Umarım bize zarar vermeden azalarak gider. Hepsini aynı anda kapatmaktan söz etmiyorum, beli hedeflerimiz var turist rakamlarını ile ilgili. Bu kadar çok özel bir ürünümüz olduğuna inanıyorum, her şey dahil satamayacağımız kadar özel olduğuna inanıyorum. Belki biz ürünümüze daha çok değer biçip satmayı öğrenmeliyiz." (K6)

“Önce Türkiye'deki restoranların standartlarını yükseltmek lazım. Alanya, Antalya, Akdeniz bölgesine gelen turist otelde yiyor, içiyor, restorana gidince de makarna pizza yiyor. Türk mutfağına özgün yediği şey pide, döner oluyor, harbi Türk mutfă̆l olarak yediği bir şey yok. Her şey dahil sistem hiçbir şey yapmıyor, açık büfe ne varsa saldırllıyor, lezzet alamıyor. Ama gelen turistlere standart yükseltilmeli. Nasıl olmal, en basit örnek Maldivler ve Seyşseller'e gittiğinizde geleneksel yemekleri bulabiliyorsunuz. Bir sürü farklı restoran var. Oteller sizi yönlendiriyor, bugün burada yiyin, bir Fransız şef Maldiv yemekleri pişiriyor, oraya gidin diyorlar. Biz de pideci, kebapçı, ya da pizza dahil her şeyi satan restoranlar var. O yüzden standart yükseltilmeli."(K7)

Öte yandan K1 nolu katılımcı her şey dahil sistemi düşman olarak görmek yerine farklı çözüm yollarını denememiz gerektiğini şu şekilde açıklamaktadır.

“.... yedi yıldızlı oteller yapıldı artık Türkiye'de. Öyle restoranlar var ki içinde. Adam girişte rezervasyon yaptırlyor. Ona göre ürün, ona göre aşçı, ona göre şov. Siz Türkiye'nin kapı girişinde alın her şey dahil diyerek. Türkiye'ye tek kart çıkartın, deyin ki arkadaş 10.000 dolar allyorum, şu şekilde, şuralara gidebilirsin, şu otellerde kalabilirsin. Farklı bir şey yapalım. Her şey dahil düşmanımız değil, neyi sattı̆̆ımı önemli."

K10 nolu katılımc1 ise; " Sektörün içinde olan bir insan olarak söylüyorum, ülkemizde hangi otele gidersen git, yabancılarla çalışan otellerde, Türk yemeklerinin yapıldiğı, Türk lezzetlerinin sunulduğu Türk günleri ve geceleri yapıllyor. Avrupa bizim lezzetlerimizi seviyor, bizim 
mutfă̆ımızda bu da olmamış dedikleri bir şey yok." diyerek sistemin tanıtımdaki hizmetini hatırlatmıştır.

\section{Sonuç ve Öneriler}

Son zamanlarda turistlerin tatil yeri seçiminde destinasyona özgü gastronomik unsurlar da önem kazanmaya başlamıştır. Bu nedenle Türkiye dünyada rekabet gücü yüksek olan kültür turizminin yanına gastronomi turizmini de eklemelidir. Bugün ülkeler kendilerini tanıtmak amacıyla yaptıkları tanıtım faaliyetlerinde yerel değerleri kullanmaktadırlar. Somut olmayan kültürel mirasın zenginliği ile mutfak kültürünü tanıtmayı başarmalıdır. Uluslararası başarının ilk koşulu doğru yapılan tanıtımdır. Başarılı bir tanıtım etkinliğinde ise ülkenin özgün ve farklı yönleri ortaya çıkarılmalıdır. Türk mutfağı sahip olduğu eşsiz ve zengin özellikleriyle doğru bir tanıtım şekli ile konumlandırılırsa, Türkiye'de gastronomi turizminin başarılı olması kaçınılmazdır. Araştırmanın bulguları incelendiğinde; katılımcılar gastro diplomasinin öncelikli olarak hayata geçirilmesi gerekliği üzerinde durmaktadırlar. Yerel yemeklerin restoranlarda ve konaklama işletmelerinde doğru şekilde sunulmasının gerekliliği söylenmektedir. Kendi mutfağımızı ve kültürümüzü korumanın öncelikli olmasına vurgu yapılmaktadır.

Kat1lımc1lara göre gastronomi turizmi, Türkiye için çok önemli bir alternatif turizm çeşididir. Türkiye'deki gastronomi turizmini değerlendirmeleri istenildiğinde popüler bir konu olduğunu düşünen ve birçok şeyin yapılabileceğine inanmaktadır. Ancak gastronomi turizmi ile ilgili daha yolun başında olduğumuz, iyi şeyler yapabileceğimiz, bunu yaparken özenli olmamız gerekliliği ortak bir görüş olarak ortaya çıkmıştır. Öte yandan gastronomi turizmini kullanılmayan bir kaynak olduğu ve bu turizm çeşidini aslında çok bilmediğimiz katılımcılar tarafindan dile getirilmektedir. Gastronomi paydaşlarının ülke içinde birlik olarak hareket etmesi gerekliği katılımcılar tarafından paylaşılmıştır. Kamu, özel sektör, eğitim kurumları ve sivil toplum kuruluşları Türkiye gastronomisi için birlikte hareket etmelidir. Etkin bir tanım faaliyeti için özel ürünler ve konseptler belirlenmesi gerekliği dile getirilmiştir.

Türk mutfağının yabancılar tarafından beğenilen bir mutfak olduğu ortak görüştür. Gastronomi kimliğini değerli kılan taklit edilememesi Türk mutfağının en güçlü yönüdür. Bundan hareketle dünyayı hakkımızda konuşturma istiyorsak, buna hayranlık uyandıracak yöresel ürünlerimizle, kaliteli restoranlarla ve başarılı şefler ile başlayabiliriz. Üç Michelin yıldızlı İtalyan şef Massimo Bottura

“Türkiye'nin Michelin yıldızlı bir restorana sahip olabilmesi için önce kendi orjinine, yani kendi geleneksel Türk mutfă̆ını vurgulaması gerekiyor. Bunu nostaljik bir yaklaşımla değil, eleştirel bir gözlemle inceleyerek günümüzün standartlarına taşıması lazım... Bu da sanat ve teknikle olur. Sanat, teknik ve yemek arasında bağlantıyı iyi bilip bu bağı kökten yaşamak gerekiyor." sözleriyle Türk mutfağı için izlemesi gereken rotayı bize tekrar hatırlatmaktadır (Foodinlife, 2015). Çalışmadan elde edilen bulgular ışığında yapılması gerekenler şu şekilde sıralanabilir:

- Federasyon ve dernekler birlikte ve koordineli hareket etme konusunda uzlaşmaya varmalıdirlar.

- Tanıtım faaliyetleri için pazarlama, marka uzmanları ve gastronomi konusunda yetkin kişiler ortak çalışmalıdırlar.

- Türk Mutfağı Araştırma Enstitüsü kurulmalıdır.

- Yöresel yemeklerin kaybolmamas1, Anadolu mutfak kültürünün devamı ve yeni nesillere doğru bir şekilde aktarılması için yazılı ve görsel kayıt çalışmaları yapılmalı, arşivlenerek bir veri tabanı oluşturulmalıdır.

- Gastronomi turizmi için seçilen şehirlerde Mutfak Araştırma Merkezleri kurulması (örn: Gaziantep Mutfak Sanatları Merkezi, Bask Mutfak Sanatları Merkezi) gerekmektedir

www.turkishstudies.net/social 
- Bakanlık ve sektör temsilcileri birlikte, dünyadaki yiyecek-içecek okullarına gönderilmek üzere yazılı bir Türk mutfağı kitabı çalışmasını, $\mathrm{Cd}$ ile birlikte hazırlanmalıdır. Farklı dillerde çevirileri yapılmalıdır.

- Turistlerin satın alabilecekleri birçok dilde hazırlanmış Türk Mutfağı kitaplarının satışı yaygınlaştırılmalıdır.

- Üniversiteler ve sektör ürün geliştirme ve pazarlama konularında birlikte proje geliştirmelidir. Yöresel ürünler ile ilgili çalışmaların ve projelerin desteklenmesi gereklidir.

- Unesco gastronomi şehirleri tanıtım faaliyetlerinde ön plana çıkarılmalıdır.

- Şehirlerin var olan yurt dışındaki kardeş şehirleri ile birlikte gastronomi etkinlikleri düzenlemelidir.

- Yerel ve bölgesel yönetimlerin gastronomi turizmi odaklı çalışmalara yönelmesi teşvik edilmelidir.

- Büyükelçilikler gastronomi etkinliklerine ağırlık vermelidir.

- İtibarımızı yükseltmek için dünyanın üç büyük şehrinde (New York, Londra ve Tokyo) Michelin seviyesinde Türk mutfağı konseptli restoranlar açılması gerekmektedir.

- Michelin Türkiye rehberinin olması için çalışmalar yapılmalıdır. Öncelikli İstanbul odaklı ve içinde Fransız, İtalyan ve dünya mutfaklarına ait restoranlarında bulunduğu, şehrin gastronomi zenginliğini gösterebilecek şekilde oluşturulmalıdır.

- Coğrafi işaret, menşee ve mahreç konularında çalışmalara aralıksız devam edilmelidir.

- Coğrafi işaretli ürün pazarı genişletilerek, tanıtım faaliyetlerinde kullanılmalıdır. Ürünlerin küresel pazarlarda, pazarlanabilecek şekilde üretilmesi gerekmektedir.

- Gastronomi turizminin tarımsal üretimden itibaren başlayan bir süreç olduğu tekrar hatırlanmalıdır.

- Gastronomi imajında yer almasını istediğimiz ürünlerin üretimleri desteklenmeli ve denetlenmelidir.

- Türk yemeklerinin Türkçe yazılıp okunması hayata geçirilmelidir.

- Restoranların menü kartlarında yiyeceklerin orijinal isimlerinin yazılı olması, yemeklerin içeriklerinin anlaşılır bir şekilde yazılması gerekmektedir.

- Gastronomi turizmi temelli tur programlarının oluşturularak, yiyecek ve içecek üretimi yapan işletmelere ziyaretleri içeren paket turlar sunulmalıdır.

- Tur programlarında yöresel yiyeceklerin olduğu tadım aktivitelerinin eklenmesi gerekmektedir.

- Yemek ve şarap rotaları öncelikli olarak hazırlanmalıdır. Ülke bazında gastronomi rotaları çıkarılmalıdır.

- Yurt dışı bağlantılı çalışan acenta ve tur operatörlerinin tanıtım broşürlerinde ve reklamlarında Türk mutfak kültürü hakkında bilgi verilmesi sağlanmalıdır.

- Hazırlanan gastronomi rehberleri acentalar vasıtasıyla farklı gruplara ulaştırılmalıdır.

- Turist rehberlerine gastronomi alanında uzmanlaşma imkanı verilmelidir.

- Sokak pazarları ve yemek kurslarının gastronomi turizminde daha etkin kullanılması sağlanmalıdır.

- Çiftlik ziyaretleri ile kırsal turizme entegre çalışmalar yapılarak gastronomi turları genişletilebilinir.

- Bakanlığın sosyal medya hesaplarının daha aktif kullanılarak, takipçi sayısının on milyona yükseltilmesi hedeflenmelidir.

- Tanıtım görsellerinde, video, film ve reklam çalışmalarında yöresel yiyeceklerin kullanılması gerekmektedir.

- Yapay zeka kullanılarak, Türkiye'ye hiç gelmeyen insanlara ulaşılması ve onlara yönelik tanıtım çalışmaları yapılması gerekmektedir. 
- Uluslararası yemek kanallarında ve yurtdışındaki ülkelerde Türk mutfak kültürüne ilişkin programların yayınlanması sağlanmalıdır.

- Dünya çapında gastronomi etkinlikleri yapılması, etkinliklerin ve festivallerin internet ortamında paylaşılması sağlanmalıdır.

- Türk kahvesinin, diğer zincir kahve markaları gibi dünyada şubeleşerek dükkanların açılması sağlanmalıdır.

- Coğrafi temelli tanıtım faaliyetleri yürütülerek Anadolu mutfağı bölge bölge tanıtılmalıdır. Anadolu'nun sahip olduğu hikayeler sofra kültürüyle birleştirilmelidir.

- Yarışma ve gastronomi organizasyonları, tanıtıma katkı sağlayacak şekilde planlanmalidir.

- Şeflerin birer tanıtım elçisi olmalarından hareketle, şefler desteklenmeli ve isimlerini dünya çapında duyurmaları sağlanmalıdır. Şefler sayesinde Türk gastronomisi açık şekilde sunulabilinir.

\section{Kaynakça}

Akgöl, Y. (2012). “Gastronomi Turizmi ve Türkiye'yi Ziyaret Eden Yabancı Turistlerin Gastronomi Deneyimlerinin Değerlendirilmesi". T.C.Mersin Üniversitesi, Sosyal Bilimler Enstitüsü, Turizm İşletmeciliği ve Otelcilik Ana Bilim Dalı, Mersin, Yüksek Lisans Tezi.

Aksungur, G. (2008). "Turizmde Markalaşma ve Tanıtma Faaliyetlerinin Önemi: Íspanya ve Türkiye'nin Karşılaştırmalı Analizi”, Uzmanlık Tezi, Ankara.

Aslan, Z., Güneren, E. ve Çoban, G. (2014). "Destinasyon Markalaşma Sürecinde Yöresel Mutfağın Rolü: Nevşehir Örneği”, Journal Of Tourism And Gastronomy Studies, C:2, No:4, ss. 3-13.

Baş, T. ve Akturan, U. (2017). Sosyal Bilimlerde Bilgisayar Destekli Nitel Araştırma Yöntemleri 3. Baskı, Ankara, Seçkin Yayıncılık,.

Bekar, A. ve Belpınar, A. (2015). "Turistlerin Gastronomi Turizmine İlișkin Görüșlerinin Milliyetlerine Göre Değerlendirilmesi”, Journal of Yasar University, C: 10, No:38, ss. 64786554.

Bezirgan, M. ve Koç F. (2014). "Yerel Mutfakların Destinasyona Yönelik Aidiyet Oluşumuna Etkisi: Cunda Adası Örneği”, Uluslararası Sosyal Araştırmalar Dergisi, Cilt: 7 Sayı: 34 ss.917928.

Boyne S. Hall D. Williams F.(2003)."Policy Support and Promotion for Food Related Tourism Initiatives: A Marketing Approach to Regional Development", Journal of Travel and Tourism Marketing, C:14, No:3-4, ss.131-154.

Cohen, E. ve Avieli, N. (2004). "Food in Tourism: Attraction and İmpediment", Annals of Tourism Research, C:31, No:4, ss.755-778.

Cömert, M. Sökmen, A. (2017). “Türkiye'de Gastronomi Turizmi: Antalya'da Konaklayan Turistler Üzerine Bir Araştırma", Seyahat ve Otel Işsletmeciliği Dergisi, C:14, No:3, ss. 6-26.

Deveci, B., Türkmen, S. ve Avcıkurt, C. (2013). Kırsal Turizm ile Gastronomi Turizmi İlişkisi: Bigadiç Örneği, Uluslararast Sosyal ve Ekonomik Bilimler Dergisi, C:3, No:2, ss. 30-31.

Durlu-Özkaya, F., Sünnetçioğlu, S. ve Can, A. (2013). "Sürdürülebilir Gastronomi Turizmi Hareketliliğinde Coğrafi İşaretlemenin Rolü”, Journal of Tourism and Gastronomy Studies, C:1, No:1, ss. 13-20.

Foodinlife (2015), (Çevrimiçi), http://foodinlife.com.tr/roportaj/297 
Güler, A., Halıcıoğlu, M.B. ve Taşğın, S. (2013) “Sosyal Bilimlerde Nitel Araştırma Yöntemleri”, 1. Bask1, Ankara: Seçkin Yayıncılık.

Hall M. ve Mitchell R., (2002)."Tourism as a Force for Gastronomic Globalization and Localization”, (Der. Hjalager A. M., Richards G.), ss. 71-87, Tourism and Gastronomy, Londra ve New York,.

Hjalager A. M.ve Corigliano M. A.(2000). "Food for Tourists - Determinants of an Image", International Journal of Tourism Research, No. 2, ss.281-293.

İçöz, O. (1990), “Türkiye'ye Yönelik Uluslararası Turizm Talebini Belirleyen Etkenler”, Turizm Y1llı̆̆ 1988-1989, Ankara.

Karim, A. S. ve Chi, C. G. Q. (2010). "Culinary Tourism as a Destination Attraction: An Empiricial Examination of Destinations Food Image", Journal Of Hospitality Marketing \& Management, C:19, No:6, ss. 531-555.

Kesici M. (2012). “Kırsal Turizme Olan Talepte Yöresel Yiyecek ve İçecek Kültürünün Rolü”, KMÜ Sosyal ve Ekonomik Araştırmalar Dergisi, C:14, No:23, ss. 33-37.

Kültür ve Turizm Bakanlığı (2018), (Çevrimiçi), http://sgb.kulturturizm.gov.tr/ Eklenti/56748,2018yili-performans-programipdf/,19.10.2018

LAWS, E.1(995). Tourist Destination Management. London: Routledge.

Lopez-Guzman T ve Sanchez-Canizares S. M. (2012). "Gastronomy Tourism and Destination Differentiation: A Case Study in Spain”, Review of Economics \& Finance, September, ss.6372

Marzella, D. A. (2008). "Culinary Tourism: Does Your Destination Have Potential", Travel Marketing Decisions. C:9, No:2, ss. 2-4.

Okumuş, B.,Okumuş, F. ve Mckercher, B., (2007)."İncorporating Local and İnternational Cuisines in The Marketing of Tourist Destinations: The Cases of Hong Kong and Turkey." Tourism Management, No:28, ss.253-261.

Okumus, F., Kock, G., Scantlebury, G. ve Okumus, B. (2013), "Using Local Cuisines When Promoting Small Caribbean Island Destinations". Journal of Travel and Tourism Marketing, C:30, No:4, ss. 410-429.

Quan, S. ve Wang, N. (2004). "Towards Structural Model Of TheTtourist Experience: An Illusstration From Food Experience in Tourism", Tourism Management, C:25, No:3, ss.297305.

Richards G. (2002). "Gastronomy: An Essential Ingredient in Tourism Production and Consumption”, (Ed. Hjalager, A.M. and Richards, G.), Tourism and Gastronomy, London: Routledge, ss. 3-20.

Santich, B. (2004). "The Study of Gastronomy and Its Relevance to Hospitality Education and Training”, Hospitality Management, No:23, ss. 15-24.

Susever, E.A. (2014). "Pazarlama İletişimi Aracı Olarak Her Şey Dahil Sisteminin Türk Mutfă̆ Tanıtımındaki Yeri”, İstanbul Maltepe Üniversitesi, Yayınlamamış Yüksek Lisans Tezi.

Tanıtma Genel Müdürlüğü (2015), (Çevrimiçi), http://www.tanitma.gov.tr/TR133608/ tanitmagenel-mudurlugu-bulteni.html/, 10.11.2017.

Tikkanen, I. (2007). "Maslow's Hierarchy and Food Tourism in Finland Five Cases", British Food Journal, C:109, No:8, ss. 721-734. 
Tolungüç, A. (2000). Turizmde Tanıtım ve Reklam. İstanbul: MediaCat Kitapları.

Tosun, C. Ve Bilim, Y.(2004). "Şehirlerin Turistik açıdan Pazarlanması: Hatay Örneği”, Anatolia: Turizm Araştırmaları Dergisi, Cilt:15, No:2, ss. 125-138.

Turizm Şurası (2018), (Çevrimiçi), http://turizmsurasi.kulturturizm.gov.tr/TR-204581/tanitma-vepazarlama-komisyonu-sonuc-raporu.html/, 04.10.2018

Tüfekci, Ö. K., Kalkan, G. ve Tüfekci, N. (2016). "Eğirdir Destinasyonunun Marka Kimlik Unsurlarının İncelenmesi: Gastronomi Kimliğine Yönelik Bir Çalışma", Journal of Tourism and Gastronomy Studies, C:4, No:1, ss. 200-214.

UNWTO (2012), (Çevrimiçi), http://cf.cdn.unwto.org/sites/all/files/docpdf/amreports4foodtourism.pdf/, 04.02.2018

Wan Y. K. P. Chan H. H. J. (2013). "Factors That Effect the Levels of Tourists' Satisfaction and Loyalty Towards Food Festivals: A Case Study of Macau", International Journal of Tourism Research, No: 15, ss.226-240.

WFTA (2016), (Çevrimiçi), https://www.worldfoodtravel.org/cpages/food-travel-monitor/, 06.01 .2018

WFTA (2018), (Çevrimiçi), https://www.worldfoodtravel.org/cpages/what-is-food-tourism/, 06.01 .2018

Yılmaz G. ve Özdemir B. (2015)."Yerel Gastronominin Tanıtım Materyallerindeki Yeri: Kapadokya Bölgesi Üzerine Bir Araştırma", I. Eurasia International Tourism Congress: Current Issues, Trends, and Indicators, Konya-Turkey, No: 2, ss.760-780.

Yurtseven H. ve R. Kaya O. (2011). "Local Food in Local Menus: The Case of Gökçeada", Tourismos: An International Multidisciplinary Journal of Tourism, No: 6, ss.263-275

Yüncü, H. R. (2009). "Sürdürülebilir Turizm Açısından Gastronomi Turizmi ve Perşembe Yaylası", 10. Aybastı-Kabataş Kurultayl, Eskişehir 